\title{
Can bacterivory sustain survival and growth in early juveniles of the bryozoan Bugula neritina, the polychaete Hydroides elegans and the barnacle Balanus amphitrite?
}

\author{
Louis A. Gosselin*, Pei-Yuan Qian
}

Department of Biology, Hong Kong University of Science and Technology (HKUST), Clear Water Bay, Kowloon, Hong Kong

\begin{abstract}
Since phytoplankton abundance can constitute a highly unpredictable source of food for suspension feeders, we examined whether early juvenile Bugula neritina, Hydroides elegans, and Balanus amphitrite can use bacteria to achieve extended survival or growth when phytoplankton is scarce. At bacterial concentrations of -2 to $3.5 \times 10^{6}$ cells $\mathrm{ml}^{-1}$, within the range of values observed in the field, early juvenile $B$. neritina and $H$. elegans were effective bacterivores, obtaining enough energy and nutrients from bacteria to sustain survival and growth. When provided with bacterial concentrations of $\sim 3 \times 10^{6}$ cells $\mathrm{ml}^{-1}$, early juvenile $B$. neritina grew as rapidly as individuals provided with abundant phytoplankton, and completed the development of a second zooid slightly earlier. At bacterial concentrations of $\sim 1 \times 10^{6}$ cells $\mathrm{mi}^{-1}$, however, early juvenile $B$. neritina fared only slightly better in terms of growth and survival than in controls where bacterial concentrations were kept to a minimum. Growth of early juvenile $H$. elegans at $-2 \times 10^{6}$ bacteria $\mathrm{ml}^{-1}$ was significantly faster than in the controls, but was nevertheless slower than in the phytoplankton treatment. Finally, Balanus amphitrite did not obtain any detectable benefit from bacteria, despite being provided with bacterial concentrations of $\sim 9 \times 10^{6}$ cells $\mathrm{ml}^{-1}$, well in excess of values observed in the field. These results indicate that early juveniles of some species are effective at using bacteria as an alternative food source, and may use bacteria as a food supplement or even as a sole source of particulate matter, if necessary, to support survival and growth. Starvation may therefore be a minor natural cause of mortality, if a cause at all, in early juvenile $H$. elegans and $B$. neritina which can use bacteria and possibly other alternative food sources when phytoplankton is scarce.
\end{abstract}

KEY WORDS: Starvation - Suspension feeding $\cdot$ Bacteria $\cdot$ Mortality $\cdot$ Development $\cdot$ Post-settlement

\section{INTRODUCTION}

The early juvenile phase in benthic marine invertebrates (cf. Gosselin 1997) is a period of high mortality, but the causes of mortality during early juvenile life, and more broadly the selective pressures during this period, remain poorly understood (Gosselin \& Qian 1997a). Food availability and energy reserves could be important selective pressures during early life history.

\footnotetext{
- Present address: Department of Biological Sciences, University College of the Cariboo (UCC), Kamloops, British Columbia V2C 5N3, Canada. E-mail: Igosselin@cáriboo.bc.ca
}

To our knowledge, however, no direct evidence that early juvenile survival or growth are constrained by food availability has been reported, although some indirect evidence suggests early juvenile benthic invertebrates could be food limited (polychaetes in soft-sediment habitats: Marsh \& Tenore 1990, Hentschel 1998).

Phytoplankton, often considered to be the main food source for suspension feeders (Langdon \& Newell 1990), varies considerably in abundance over time and space (Langdon \& Newell 1990, Cloern 1991, Pae \& Yoo 1991, Pitcher et al. 1991, Ziemann et al. 1991, Litaker et al. 1993) and can constitute a highly unpredictable source of food. In addition, competition for food can lead to food limitation in newly settled sus- 
pension feeders even when phytoplankton is abundant (Zajac et al. 1989). Starvation would be minimized, however, if early juveniles could also effectively capture and assimilate non-phytoplanktonic sources of organic matter. For instance, larvae of the polychaete Hydroides elegans can feed effectively on bacteria (Gosselin \& Qian 1997b), and larvae of the oyster Crassostrea gigas (Douillet 1993) can cover part of their metabolic requirements through bacterivory. At metamorphosis, however, suspension feeding organs of invertebrate larvae may be modified or replaced, such that the ability of the early juvenile to use bacteria as a food source may differ from that of the larvae.

Models of particle encounter and clearance rates suggest that bacteria-sized particles $(\sim 1 \mu \mathrm{m})$ should be less effectively captured than larger particles, but may nevertheless constitute a significant food resource for suspension feeding invertebrates (Shimeta \& Jumars 1991, Shimeta 1993). Empirical studies focussing on late juveniles or adults of suspension feeding benthic invertebrates, in most cases on bivalves, have shown that some do filter very small particles from the water column (Crosby et al. 1990). For instance, the mussels Geukensia demissa and Mytilus edulis can consume bacteria-sized particles $(<1 \mu \mathrm{m})$ with capture efficiencies of 5 to $30 \%$ and assimilation efficiencies of 21 to $44 \%$ (Wright et al. 1982, Lucas et al. 1987, Langdon \& Newell 1990, Kreeger \& Newell 1996). In freshwater systems, zebra mussels Dreissena polymorpha capture cells as small as $0.4 \mu \mathrm{m}$ in diameter (Cotner et al. 1995). Marine sponges can also be highly effective bacterivores (Reiswig 1971, Pile et al. 1996). It is therefore possible that bacteria are also used as food during the early juvenile phase in suspension feeders. But whether newly metamorphosed early juveniles do consume bacteria and whether bacteria are sufficient to support survival or growth when phytoplankton is scarce have not been explored.

The goal of this study was therefore to determine if bacteria can be used as a food source by early juveniles of a bryozoan (Bugula neritina), a polychaete (Hydroides elegans), and a barnacle (Balanus amphitrite). Specifically, we examined whether early juveniles of these 3 species can use bacteria to sustain survival and growth, as well as the development of new zooids in B. neritina.

\section{MATERIALS AND METHODS}

Study site, organisms, and general methods. All early juveniles used in the present study were obtained through laboratory culture. Gametes (Hydroides elegans) or larvae (Bugula neritina, Balanus amphitrite) were released by mature adults that had been collected in Port Shelter $\left(22^{\circ} 9^{\prime} \mathrm{N}, 114^{\circ} 16^{\prime} \mathrm{W}\right)$, a bay in eastern Hong Kong waters. All 3 species are common in Hong Kong coastal waters (Morton \& Morton 1983) and are widely distributed throughout the world. To abtain larvae of $B$. neritina, adult colonies were collected from ropes suspended in Port Shelter and placed in aerated containers in the dark overnight. The next morning, B. neritina colonies were exposed to bright light, stimulating the release of larvae, as described for Bugula stolonifera by Woollacott et al. (1989). B. neritina larvae are lecithotrophic and settle within hours of being released.

Spawning techniques for Hydroides elegans and Balanus amphitrite were as described by Gosselin \& Qian (1997b). H. elegans larvae were provided with the dinoflagellate Isochrysis galbana (Tahitian), whereas $B$. amphitrite larvae were fed the diatom Skeletonema costatum. Larvae of both species reached competence to metamorphose within $5 \mathrm{~d}$.

Preparation of treatment suspensions. All experiments described below included 3 food treatments: control, bacteria, and phytoplankton. The phytoplankton treatment served to assess early juvenile performance in conditions of unlimited access to phytoplankton, whereas the control treatment served to assess performance in the absence of phytoplankton and with minimal bacteria. Details of the culture and preparation methods for each type of suspension are given in Gosselin \& Qian (1997b).

The dinoflagellate Isochrysis galbana was provided in the phytoplankton treatments of the Bugula neritina and Hydroides elegans experiments, whereas the diatom Skeletonema costatum was provided in the Balanus amphitrite experiment. These diets were used based on preliminary work and published reports indicating that larvae and juveniles of these invertebrates readily feed, survive, and grow when provided the corresponding microalgal species. Phytoplankton treatment suspensions contained $10^{5}$ to $10^{6}$ cells $\mathrm{ml}^{-1}$, ensuring early juveniles could feed ad libitum. Bacteria treatment suspensions were prepared with 4 strains of heterotrophic marine bacteria isolated from surface water in Port Shelter (see Table 1 for cell types and sizes). Equal amounts $(1 \mathrm{ml})$ of original stock of each bacterial strain were used to inoculate bacterial cultures (as described in Gosselin \& Qian 1997b), but the actual proportions of each strain in the final solutions provided to the early juveniles was not monitored. Also, preparation procodures for the present study wore aimed at producing approximate ratirer than exact bacterial concentrations. Average natural concentrations of bacteria in surface waters of Port Shelter ranged from 0.63 to $3.94 \times 10^{\dagger}$ cells m1-1 during most of the year (Gosselin \& Qian 1997b); concentrations used in bacteria treatments of Expts 1 to 3 were kept within this range. 
Table 1 . Cell shape and size of the 4 bacteria strains, and cell size of Isochrysis galbana. Each value was calculated from measurements of 20 replicate cells from laboratory cultures. Bacteria strain numbers correspond to strains described by Lau \& Qian (1997)

\begin{tabular}{|lcc|}
\hline & Cell shape & $\begin{array}{c}\text { Cell diameter or } \\
\text { length }(\mu \mathrm{m} \pm \mathrm{SD})\end{array}$ \\
\hline Bacteria strain no. 4 & Cocci & $1.25 \pm 0.10$ \\
Bacteria strain no. 10 & Rod & $1.47 \pm 0.30$ \\
Bacteria strain no. 11 & Rod & $1.33 \pm 0.24$ \\
Bacteria strain no. 12 & Rod & $1.11 \pm 0.26$ \\
Isochrysis galbana & - & $6.8 \pm 1.2$ \\
\hline
\end{tabular}

Control treatment solutions were obtained by filtering part of the bacterial treatment suspension through a $0.22 \mu \mathrm{m}$ membrane, thereby obtaining a particle-free solution with a similar initial content of dissolved materials, including dissolved organic matter, as in the bacteria treatment. Three steps were taken to minimize bacterial content in the control treatment: (1) treatment suspensions were prepared with autoclaved artificial seawater, made with reagent grade chemicals and distilled water, to minimize the availability of nutrients; (2) all material coming into contact with treatment suspensions were rinsed in distilled water and autoclaved daily; and (3) treatment suspensions and culture beakers were replaced daily. The same procedures were also repeated for bacteria and phytoplankton treatments to standardize their effects.

Bacterial concentrations in treatment suspensions. Bacterial concentrations were determined by examining aliquots of treatment suspensions stained with Acridine Orange and filtered onto a polycarbonate filter. The procedure was carried out as described by Turley (1993) and by Suzuki et al. (1993). In Expts 1, 2, and 3 , bacterial concentrations in the treatment suspensions were determined on one of the days of the experiment, just before the early juveniles were added, and again $1 \mathrm{~d}$ later, immediately after the early juveniles were removed and transferred to fresh suspensions. In Expt 4, due to time constraints, bacterial concentrations were determined only once, prior to adding early juveniles.

Expt 1: Bugula neritina at low bacterial concentrations. The goal of the first experiment was to determine if newly metamorphosed Bugula neritina can feed on bacteria and obtain enough energy and nutrients to sustain survival, growth, and the development of new zooids. Bacterial densities were set at $\sim 1 \times 10^{6}$ cells $\mathrm{ml}^{-1}$.

Within $3 \mathrm{~h}$ of spawning, larvae were transferred to several $50 \mathrm{ml}$ clear polypropylene centrifuge tubes (Corning ${ }^{\circledast 2}$ no. 25330-50). The tubes were capped and placed on their sides for $2 \mathrm{~h}$, during which time most larvae attached to the inner surface of the tubes. Centrifuge tubes were then carefully cut into rings 5 to $8 \mathrm{~mm}$ high, each ring bearing several settlers on the inner surface. These rings were placed overnight at $22^{\circ} \mathrm{C}$ in a $1 \mathrm{l}$ beaker of autoclaved artificial seawater (ASW) containing antibiotics $\left(150 \mu \mathrm{g} \mathrm{m} \mathrm{m}^{-1}\right.$ Streptomycin sulphate and $100 \mu \mathrm{g} \mathrm{ml}^{-1}$ Penicillin G sodium salt). The next day, all but 10 well-spaced early juveniles were removed from each ring. The rings were then returned to ASW with antibiotics for a further $24 \mathrm{~h}$ to allow the ancestrulae to complete their development and be ready to begin feeding. At this time, $2 \mathrm{~d}$ after spawning, the body heights of 60 haphazardly selected individuals were measured under a dissecting microscope (measured from the attachment disc to the highest point above the surface, including the bud but excluding the lophophore).

Rings were then haphazardly allocated to 1 of the 3 treatments, 6 replicate rings per treatment (experimental design: 3 treatments $\times 6$ rings per treatment $\times$ 10 early juveniles per ring). Each ring was rinsed in fresh autoclaved ASW and then transferred to beakers containing $60 \mathrm{ml}$ of treatment suspension, 1 ring per beaker, at $22^{\circ} \mathrm{C}$. Every day, each ring was rinsed in fresh autoclaved ASW and transferred to new treatment suspensions. Starting on Day 3, and on every second day thereafter, the number of surviving colonies and the number of complete zooids per colony were determined and dead colonies were gently removed. At the end of the experiment, the height of all remaining colonies was measured.

Fecal pellets were noticed on the bottom of some of the culture beakers in which early juveniles had spent the last $24 \mathrm{~h}$. The number of pellets on the bottom of each beaker was therefore counted on Day 3, after transferring the rings to new suspensions, and the length and width of 20 pellets from the phytoplankton and bacteria treatments were measured under a dissecting microscope to evaluate the amount of particulate material processed in the previous $24 \mathrm{~h}$.

Expt 2: Bugula neritina at moderate bacterial concentrations. Expt 1 revealed that early juveniles did feed on bacteria, but many died nevertheless. This second experiment was therefore carried out with a new set of early juvenile Bugula neritina to determine if they would be more successful with a greater supply of bacteria. This second experiment was similar to Expt 1 , but with higher cell concentrations in the bacteria treatment and a reduced experimental design. The bacteria treatment of Expt 2 was prepared so as to have concentrations of $-3 \times 10^{6}$ cells $\mathrm{ml}^{-1}$, which is close to the upper end of the range of concentrations observed in the field. In addition, Expt 2 consisted of 3 replicate rings per treatment and lasted $9 \mathrm{~d}$, with all observations of survival, growth, and development 
being done only once at the end of the experiment (experimental design: 3 treatments $\times 3$ rings per treatment $\times 10$ early juveniles per ring).

Expt 3: Hydroides elegans. The third experiment examined whether newly metamorphosed Hydroides elegans could obtain enough energy and nutrients from bacteria to support survival and growth. Cell concentrations in the bacteria treatment were set at $-2 x$ $10^{6}$ cells $\mathrm{mi}^{-1}$

Competent larvae were placed in Falcon ${ }^{\circledR}$ no. 1006 petri dishes containing $0.22 \mu \mathrm{m}$ filtered seawater (FSW) with antibiotics in an incubator at $22^{\circ} \mathrm{C}$. After $24 \mathrm{~h}$, unattached larvae were discarded and excess settlers were dislodged from each dish, leaving 6 to 7 evenly spaced early juveniles, with well-formed tentacles and tubes, per dish section (bottom or lid). Fresh FSW with antibiotics was again added to each dish for $1 \mathrm{~d}$, after which tube lengths of individuals in 9 out of 18 dishes were measured under a dissecting microscope. Dishes were haphazardly allocated to each treatment, but with each treatment receiving 3 of the dishes used to measure initial tube lengths (experimental design: 3 treatments $\times 6$ dishes per treatment $\times$ 6 to 7 early juveniles per dish)

Each dish was then rinsed in $500 \mathrm{ml}$ of distilled water for $20 \mathrm{~s}$ to destroy surface bacteria and then transferred to beakers containing $60 \mathrm{ml}$ of treatment suspension at $22^{\circ} \mathrm{C}, 1$ dish per beaker. The dishes were rinsed every day in FSW and transferred to a new treatment suspension; dead individuals were identified and marked every $3 \mathrm{~d}$. During the first $3 \mathrm{~d}$, half of the early juveniles died, with approximately equal mortality among the 3 treatments, possibly as a result of the initial rinsing in distilled water. Since mortality was low during the following days, survivorship was calculated starting on Day 3 rather than on Day 0. On Day 18, tube lengths of all live worms were measured. Since many worms had grown curved tubes, tubes were individually captured on video and digitally measured using Optimas image analysis software.

Expt 4: Balanus amphitrite. Expt 4 determined if newly metamorphosed Balanus amphitrite can use bacteria to sustain growth. This experiment lasted $6 d_{\text {i }}$ equipment problems then prevented further experimentation to examine survivorship. Based on preliminary observations that had suggested early juvenile $B$. amphitrite do not obtain detectable benefits at low

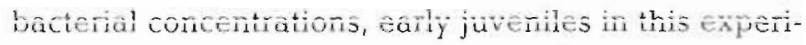
ment were provided with abundant bacteria, at concentrations of $\sim 9 \times 10^{6}$ cells $\mathrm{ml}^{-1}$.

Cyprid larvae were placed in Falcon ${ }^{\otimes}$ no. 1006 petri dishes with FSW; enough cyprids had settled after $4 \mathrm{~d}$ to begin the experiment. Early juveniles in corners or next to other individuals were removed, leaving 1 or 2 early juveniles in each of the 15 dish sections (bottom or lid). For each early juvenile, an individual mark was placed on the opposite side of the petri dish and the shell diameter was measured along the rostro-carinal axis. Each dish was then filled with distilled water for 10 min to minimize surface bacteria, after which the distilled water was replaced by 1 of the 3 treatment suspensions (experimental design: 3 treatments $\times 7$ dishes per treatment $\times 1$ to 2 early juveniles per dish). The dishes were sealed and placed in an incubator at $27^{\circ} \mathrm{C}$ on a gently rotating plate to keep Skeletonema costatum cells in suspension. Each day, the dishes were briefly rinsed in distilled water and fresh treatment suspension was added. On Day 6, the shell diameter of each live barnacle was measured a second time, allowing the determination of growth for each individual.

Statistical analyses. All data were tested for normality and homogeneity of variances prior to statistical comparisons of means. Datasets that were non-normal or heteroscedastic were transformed using log or square root transformations, and these transformations satisfied the requirements for parametric analysis.

\section{RESULTS}

\section{Bacterial concentrations in treatment suspensions}

Cell concentrations in the bacteria treatments dropped in Expts 1, 2 (Bugula neritina), and 3 (Hydroides elegans) after $1 \mathrm{~d}$ with early juveniles, whereas concentrations increased (controls) or varied (phytoplankton) in other treatments (Fig. 1A,B). Some bacterial growth did occur in controls, but concentrations in this treatment remained relatively low.

\section{Expt 1: Bugula neritina at low bacterial concentrations}

Several early juvenile Bugula neritina in the bacteria treatment died during the $17 \mathrm{~d}$ of this experiment, but on average survived longer than in the controls (Fig. 2A), Survivorship at the end of the experiment was significantly different among treatments (ANOVA: $n=$ $18 \mathrm{df}=17, F=67.17, \mathrm{p}<0.001$ ), with survivorship in the bacteria treatment being significantly higher than in the contiols bit lower than in the phytuplantum treatment (Tukey test, $\alpha=0.05$ ).

Most Bugula neritina in the bacteria treatment grew, although not as much as in the phytoplankton treatment (Fig. 2B). To test for differences among treatments on Day 17, the body height of ali individuals within a dish were pooled to obtain an average height 


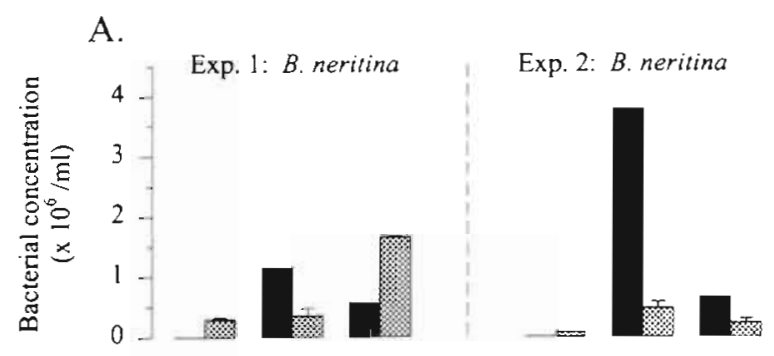

B.

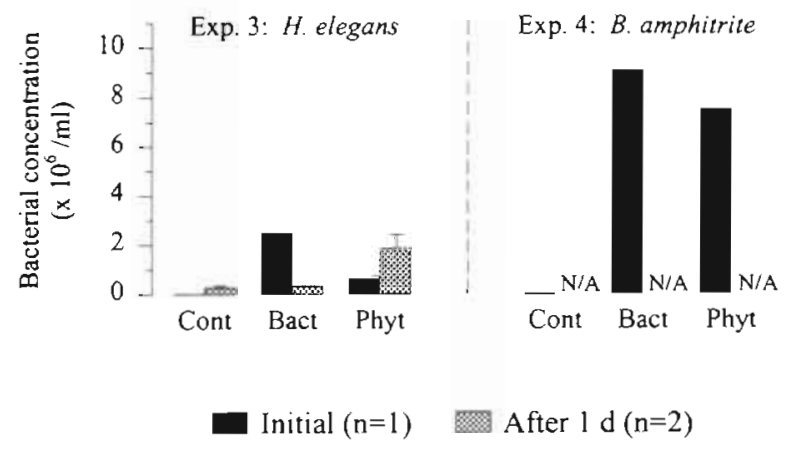

Fig. 1 Average bacterial concentrations in control (Cont), bacteria (Bact), and phytoplankton (Phyt) suspensions of the 4 experiments. For each of these experiments, bacterial concentrations were determined for the stock suspensions prior to adding early juveniles ('Initial' values). For Expts 1, 2 and 3, concentrations were also determined a second time in 2 replicates of each treatment after the early juveniles had spent $24 \mathrm{~h}$ in the suspensions ('After $1 \mathrm{~d}$ ' values). No second assessment of bacterial densities were carried out in Expt 4

per dish, and the average value from each dish was then used in an ANOVA (Hurlbert 1984). Since all individuals in one of the control dishes had died by Day 17. size data were obtained from 5 replicate control dishes rather than 6 . Body height on Day 17 differed significantly among treatments (ANOVA: $\mathrm{n}=17, \mathrm{df}=16, F=$ $206.45, \mathrm{p}<0.001$ ), with individuals in the bacteria treatment being significantly taller than in the controls but shorter than in the phytoplankton treatment (Tukey test, $\alpha=0.05$ ). By Day 17 , the buds of 4 early juvenile $B$. neritina in the bacteria treatment had developed into a functional second zooid with extended lophophores (Fig. 3). In the controls, the buds of all surviving $B$. neritina had largely resorbed and appeared empty when viewed under the microscope. Rapid growth of buds in the phytoplankton treatment, however, led to the development of 1 to 4 new zooids per colony during the course of the experiment (Fig. 3).

Early juvenile Bugula neritina in the bacteria treatment were clearly capturing and ingesting bacteria, as evidenced by their production of fecal pellets. Fecal pellets in this treatment were white and similar in appearance to the bacterial pellets obtained when centrifuging suspensions of bacteria. In the phytoplankton treatment, fecal pellets were yellow to orange, indicating that many phytoplankton cells had been ingested. Early juveniles in the 6 control replicates produced a total of only 3 fecal pellets in the $24 \mathrm{~h}$ period, indicating that very small amounts of bacteria were captured; these 3 pellets were irregular in shape and were not measured. In the bacteria and in the phytoplankton treatments, however, 13 to $18 \mathrm{fecal}$ pellets were produced on average by each early juvenile during the same $24 \mathrm{~h}$ period (Table 2). These observations were made on Day 3 of the experiment, at which time all $B$. neritina had only 1 zooid (the ancestrula). Average production of fecal material, an indicator of food processing rate, was $5.85 \times 10^{-3} \mu \mathrm{l} \mathrm{zooid}^{-1} \mathrm{~d}^{-1}$ in the bacteria treatment, and $25.18 \times 10^{-3} \mu \mathrm{l}$ zooid $^{-1} \mathrm{~d}^{-1}$ in the phytoplankton treatment (calculated as volume per pellet $\times$ no. pellets zooid ${ }^{-1} d^{-1}$, Table 2 ).

\section{Expt 2: Bugula neritina at moderate bacterial concentrations}

In Expt 2, which used higher cell concentrations in the bacteria treatment $\left(\sim 3 \times 10^{6}\right.$ cells $\left.\mathrm{ml}^{-1}\right)$ than in Expt $1\left(\sim 1 \times 10^{6}\right.$ cells $\left.\mathrm{ml}^{-1}\right)$, early juvenile Bugula ner-
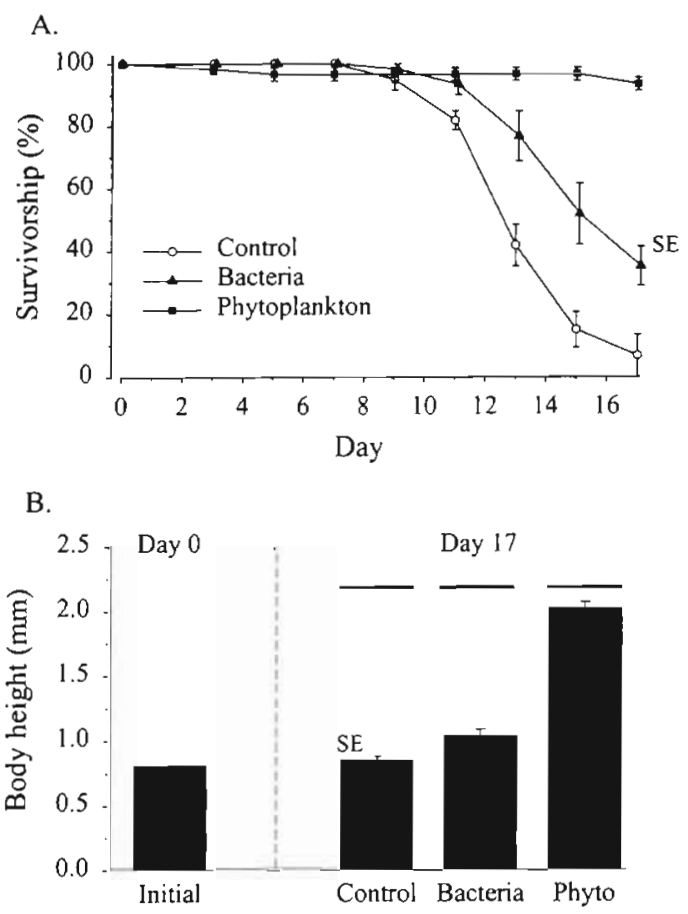

Fig. 2. Bugula neritina, Expt 1. (A) Survivorship of early juvenile $B$. neritina during Expt 1 . (B) Average body height of newly metamorphosed $B$. neritina at the start of Expt 1 ('Initial'), and after $17 \mathrm{~d}$ in each of the 3 treatments. Horizontal lines above the graph link values from Day 17 that are not significantly different, as determined by a Tukey multiple comparisons test at $\alpha=0.05$ 


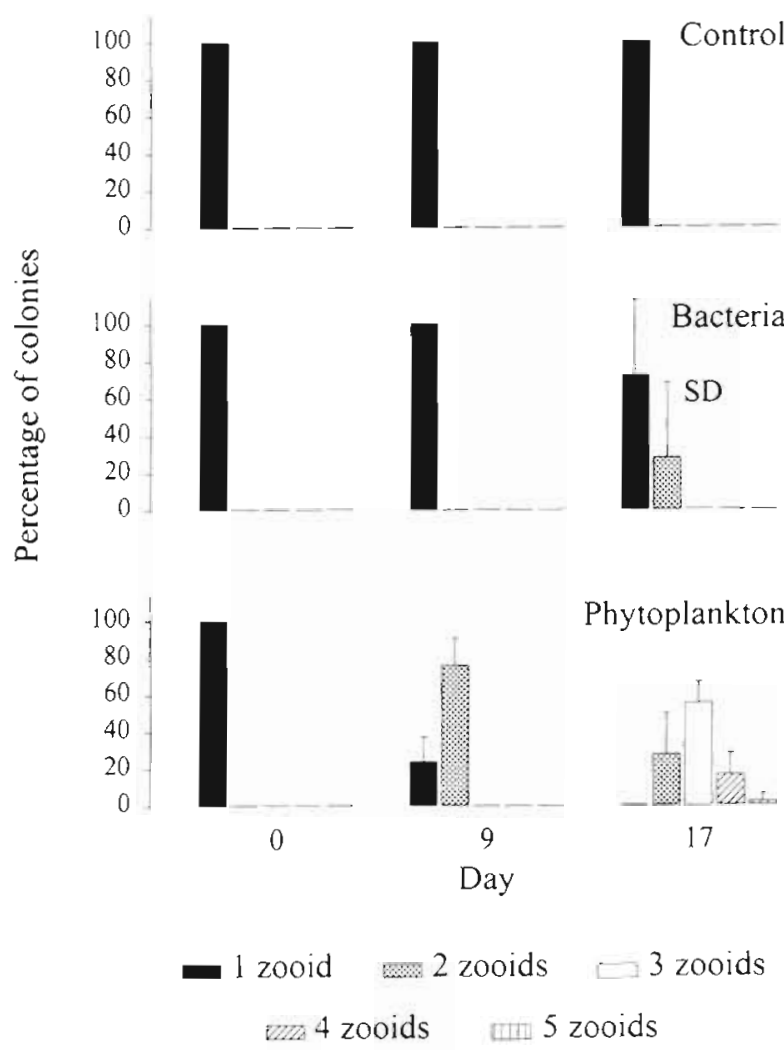

Fıy. 3. Bugula neritina, Expt 1. Development of B. neritind colonies in each treatment, as determined by the percentage of live colonies with 1 to 5 functional zooids, on Days 0.9 , and 17 of the experiment

itina in the bacteria treatment performed better than in Expt 1 As expected from the results of Expt 1, few individuals died during this $9 \mathrm{~d}$ experiment, with 83, 93, and $100 \%$ survival in the control, bacteria, and phytoplankton treatments, respectively (ANOVA. $\mathrm{n}=$ 9, $\mathrm{df}=8, F=1.36, \mathrm{p}=0.326$ ).

The increased bacterial concentration did make a noticeable difference, however, in growth and development. To test for differences among treatments on Day 9 , the body height of all individuals within a dish
A.

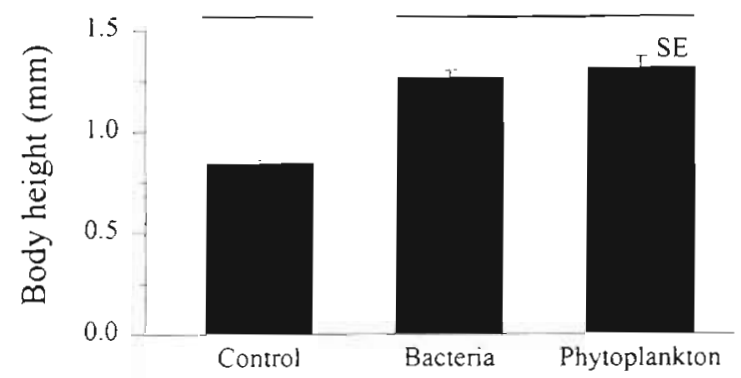

B.

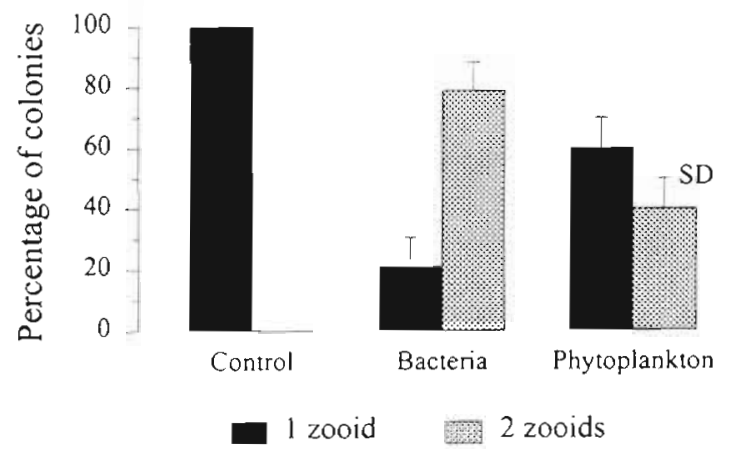

Fig. 4. Bugula neritina, Expt 2. (A) Average body height of $B$. neritina after $9 \mathrm{~d}$ in each of the 3 treatments. Horizontal lines above the graph link values that are not significantly different, as determined by a Tukey multiple comparisons test at $\alpha$ $=0.05$. (B) Development of $B$. neritina colonies in each treatment, as determined by the percentage of colonies with 1 or 2 functional zooids on Day 9 of the experiment (no colony had completed a third zooid)

was pooled to obtain an average height per dish, and the average value from each dish was then used in an ANOVA (Hurlbert 1984). Average body heights on Day 9 (Fig. 4 A) were significantly different among treatments (ANOVA: $\mathrm{n}=9, \mathrm{df}=8, F=45.45, \mathrm{p}<0.001$ ); body heights in the bacteria and phytoplankton treatments were not significantly different, and both were greater than in the controls (Tukey test, $\alpha=0.05$ ). Individuals in the bacteria treatment completed the development of a second functional zooid slightly faster than

Table 2. Bugula neritina, Expt 1. Features of fecal pellets produced by early juvenile $B$. neritina in the 3 treatments of Expt 2 Values are presented as averages \pm SD. Pellet volume was calculated using the volume of a cylinder as a close approximation

\begin{tabular}{|c|c|c|c|}
\hline & Contro! & Bacteria & Phytoplankton \\
\hline Pellet colour: & White/translucent & White/translucent & Yellow/orange \\
\hline \multicolumn{4}{|l|}{ Pellet dimensions: $(n=20$ treatment $)$} \\
\hline Length & - & $158.1 \pm 12.2 \mu \mathrm{m}$ & $178.9 \pm 17.8 \mathrm{\mu m}$ \\
\hline Width & - & $59.8 \pm 4.8 \mu \mathrm{m}$ & $99.5 \pm 8.5 \mu \mathrm{m}$ \\
\hline Calculated volume per pellet & - & $0.45 \pm 0.08 \times 10^{1} \mu 1$ & $1.40 \pm 0.25 \times 10^{3} \mu 1$ \\
\hline No. of pellets zooid-1 $\mathrm{d}^{-1} \mid \mathrm{n}=6$ treatment ${ }^{\mathrm{i}}$ ) & $0.1 \pm 0.1$ & $13.0 \pm 1.5$ & $18.0 \pm 1.0$ \\
\hline
\end{tabular}



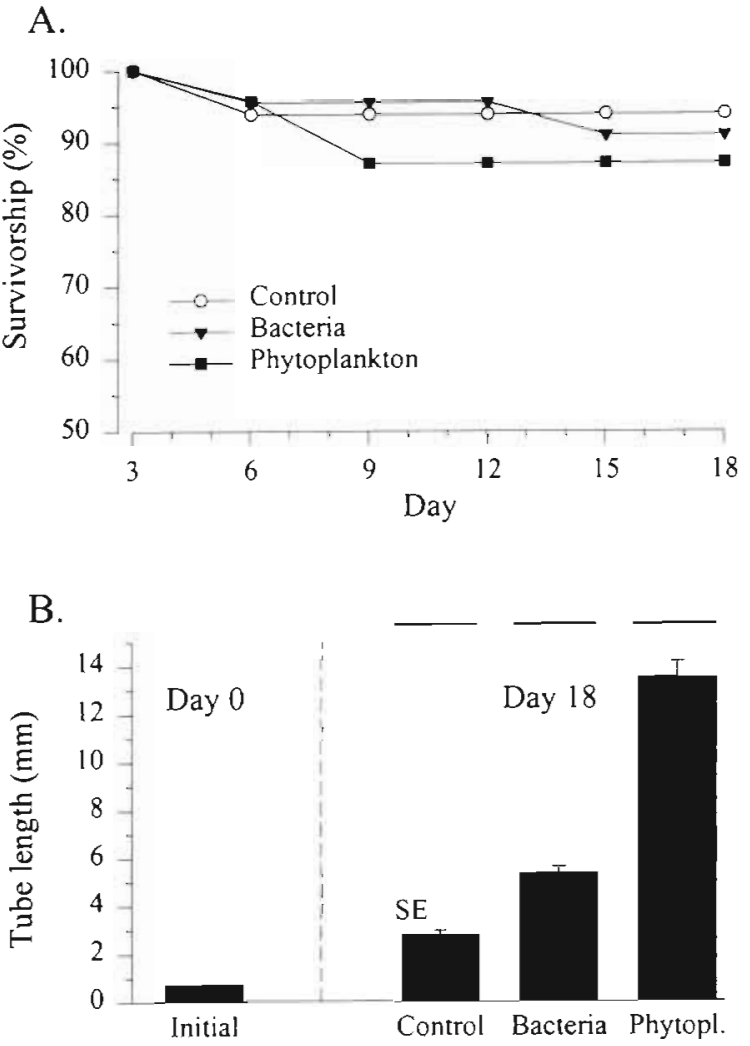

Fig. 5. Hydroides elegans, Expt 3. (A) Survivorship of early juvenile $H$. elegans during Expt 3 . Survivorship is plotted from Day 3 because of high initial mortality in all treatments, possibly caused by manipulations (see 'Materials and methods: Expt 3'). (B) Average tube length of newly metamorphosed $H$. elegans at the start of Expt 3 ('Initial'), and after $18 \mathrm{~d}$ in each of the 3 treatments. Horizontal lines above the graph link values from Day 18 that are not significantly different, as determined by a Tukey multiple comparisons test at $\alpha=0.05$

in the phytoplankton treatment (Fig. 4B), although development of the second zooid was also near completion in most other ancestrulae of the bacteria and phytoplankton treatments.

\section{Expt 3: Hydroides elegans}

Survivorship of Hydroides elegans remained high throughout Expt 3 (Fig. 5A). Since most dishes in this experiment were left with fewer than 4 live worms on Day 3 (see 'Materials and methods'), calculations of survivorship per replicate dish were not appropriate; data were therefore pooled to obtain overall survivorship per treatment.

Early juvenile Hydroides elegans in the bacteria treatment grew faster than in the controls (Fig. 5B). To test for differences among treatments on Day 18, the average tube length of all individuals within a dish was pooled to obtain average length per dish, and the average value from each dish was then used in an ANOVA (Hurlbert 1984). Average tube lengths in the 3 treatments on Day 18 were significantly different (ANOVA: $\mathrm{n}=18, \mathrm{df}=17, F=180.8, \mathrm{p}<0.001$ ), with the tubes of individuals in the bacteria treatment being significantly longer than in the controls but shorter than in the phytoplankton treatment (Tukey test, $\alpha=0.05$ ). Interestingly, some growth was also apparent among all individuals in the controls. Fecal material was observed at the posterior ends of the tubes in each treatment, including the controls, indicating that all early juveniles were capturing and ingesting some particulate material. By Day 18 , some individuals in the phytoplankton treatment had matured and contained masses of gametes; no individual in the bacteria or control treatments had yet reached maturity.

\section{Expt 4: Balanus amphitrite}

During the $6 \mathrm{~d}$ of Expt 4, only 3 early juvenile Balanus amphitrite died: 2 in the phytoplankton treatment and 1 in the bacteria treatment. To test for differences in shell growth among treatments, growth increments of individuals in dishes containing $2 \mathrm{~B}$. amphitrite were pooled to obtain average growth per dish; a single growth value from each dish was then used in an ANOVA (Hurlbert 1984). Mortality during the experiment resulted in having 2 replicate dishes with no barnacles on Day 6, therefore providing a total of 19 growth values instead of 21 . Growth differed significantly among treatments (ANOVA: $\mathrm{n}=19$, df $=18, F=$ 65.64, $\mathrm{p}<0.001)$. Early juvenile barnacles in the phytoplankton treatment grew substantially, whereas those in the bacteria and control treatments did not grow (Fig. 6).

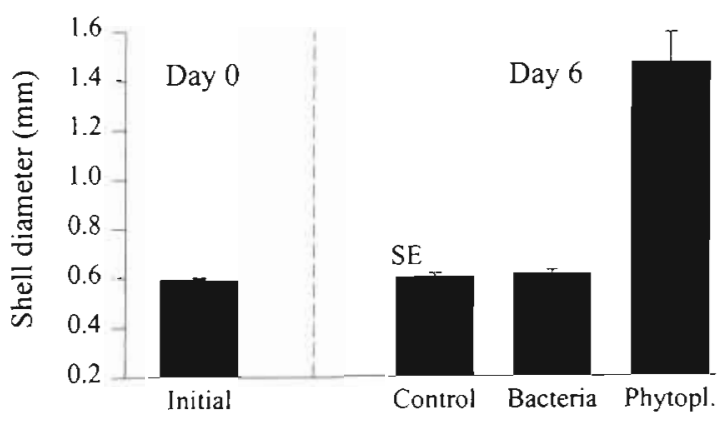

Fig. 6. Balanus amphitrite, Expt 4. Average shell diameter of newly metamorphosed $B$. amphitrite at the start of Expt 4 ('Initial'), and after $6 \mathrm{~d}$ in each of the 3 treatments 


\section{DISCUSSION}

\section{Bacterivory by early juveniles}

The effectiveness of early juveniles in using bacteria as a food source varied considerably among the 3 species. Early juvenile Bugula neritina and Hydroides elegans did capture and consume bacteria, and at moderately high bacterial concentrations they obtained enough energy and nutrients from bacteria to sustain survival and growth. Balanus amphitrite did not obtain any detectable benefit from bacteria, despite the high bacterial concentrations that were provided.

Bugula neritina captured and ingested bacteria, as evidenced by the production of fecal pellets in Expt 1 at low bacteria concentrations. When $B$. neritina in Expt 2 were provided with bacterial concentrations of $-3 \times 10^{6}$ cells $\mathrm{ml}^{-1}$, a level within the range of concentrations observed in the field, the early juveniles were able to grow as rapidly as individuals provided with abundant phytoplankton, and completed the development of a second zooid slightly earlier. This suggests that an adequate supply of bacteria could constitute as good a food source to young $B$. neritina as phytoplankton (Isochrysis galbana). The low survivorship and growth of $B$. neritina in the bacteria treatment of Expt 1, as well as the lower production of fecal material relative to that in the phytoplankton treatment, seem to indicate that bacterial concentrations of $\sim 1 x$ $10^{6}$ cells $\mathrm{ml}^{-1}$ are below the minimum threshold of food availability for early juvenile $B$. neritina. However, this outcome may have been a consequence of the depletion of bacteria in the suspensions, as bacterial concentrations dropped to $\sim 0.4 \times 10^{6}$ cells $\mathrm{ml}^{-1}$ after $1 \mathrm{~d}$. Localized depletion in the field may not occur to such an extent due to the greater pool of bacteria in the water mass. Some depletion of bacteria by suspension feeding animals has nevertheless previously been recorded in laboratory experiments and in the field (Schleyer 1981, Lucas et al. 1987)

Newly settled Hydroides elegans were also able to obtain enough energy and nutrients to sustain growth in the absence of phytoplankton. It is significant that very low mortality of $H$. elegans was observed in the controls during the $18 \mathrm{~d}$ of Expt 3 , and that individuals in the controls actually grew, on average, by $\sim 400 \%$ (tube length). Most nutrition obtained by $H$. elegans in the controls may have come from bacteria, despite the low availubility of bactoria in this troatment (Fig. 1 $\mathrm{B}$ ); small amounts of fecal material present at the posterior end of the tubes indicated that individuals were indeed capturing and ingesting some bacteria. Some organic material, however, may have been obtained from the uptake of dissolved organic matter, the only other potential source of organic matter in control treat- ments. Growth of early juvenile $H$. elegans in the bacteria treatment was significantly faster than in the controls, but was less than half as fast as in the phytoplankton treatment. As suggested above for Bugula neritina in Expt 1, this slower growth may have been partly due to the depletion of bacteria in the bacteria treatment, which dropped from $2.49 \times 10^{6}$ to $0.36 \times 10^{6}$ cells $\mathrm{ml}^{-1}$ in $1 \mathrm{~d}$. Growth of early juveniles in the bacteria treatments may also have been constrained by dietary deficiencies, as bacteria lack certain compounds used by marine metazoans (Phillips 1984).

Early juvenile Balanus amphitrite did not grow when provided with abundant bacteria as the sole particulate food source. Consequently, B. amphitrite do not appear to feed on bacteria during this phase, as is also the case during the larval phase of this species (Gosselin \& Qian 1997b)

\section{Ecological implications}

Previous studies of bacterivory by postmetamorphic suspension feeding invertebrates have focussed almost exclusively on late juvenile or adult bivalves, and found that bacterivory could sustain part but not all basic metabolic requirements of the individual (Crosby et al, 1990, Langdon \& Newell 1990, Cotner et al. 1995, Kreeger \& Newell 1996). The present study, using bacterial strains isolated from Port Shelter and at concentrations commonly occurring in that area, indicates that early juvenile Bugula neritina and Hydroides elegans might obtain enough energy and nutrients from bacteria to cover all basic metabolic requirements and some growth as well. Whether this is achieved in the field will partly depend on the size range of available bacteria and on ambient flow rate. Cell sizes of bacteria used in the present experiments were not large (Table 1). Nevertheless, bacteria in laboratory cultures can attain larger sizes than in the field (Lee \& Fuhrman 1987), and so bacterial availability in our experimental suspensions may have been higher than is suggested by cell concentrations alone. Models of suspension feeding in flows ranging from 0 to $1.1 \mathrm{~cm} \mathrm{~s}^{-1}$ suggest that particle encounter and capture rates are low in still water (as existed in our Expts 1,2 and 3), and increase with increasing flow (Shimeta \& Jumars 1991, Shimeta 1993). As flows increase from 1 to $12 \mathrm{~cm} \mathrm{~s}^{-1}$, particle capture in some bryozoan species decreases (most exporiments used 9.6 to $19.5 \mathrm{\mu m}$ particles; Okamura 1990, 1992). However, early juveniles are very small and their feeding structures are located close to the substratum, in the region of the boundary layer where flow remains slowest: this position is the least likely to experience turbulence or high flow rates that could interfere with feeding. 
Since bacteria can be used as an alternative food source by early juvenile Hydroides elegans or Bugula neritina when other sources, such as phytoplankton, are scarce, starvation may not be an important natural cause of early juvenile mortality in these species. Susceptibility to starvation early in life is further reduced in these species by the fact that their larvae are not dependent on phytoplankton: $H$. elegans can complete larval development and metamorphose into healthy early juveniles using bacteria as the sole particulate food source (Gosselin \& Qian 1997b), whereas B. neritina larvae are lecithotrophic (although they do take up dissolved organic matter, Jaeckle 1994). Survivorship through early life may therefore be unrelated to phytoplankton abundance in these species. However, our results indicate that a diet composed mainly of bacteria may sustain less than maximum growth rates in early juveniles of these species, especially when bacterial abundance in the field is modest.

Starvation may be more of a problem in early juvenile Balanus amphitrite, which do not use bacteria as a food source. However, heterotrophic bacteria are only one of several non-phytoplanktonic forms of organic matter available to suspension feeding benthic marine animals. Other forms include dissolved organic matter, inert particles, cyanobacteria, protozoans, and zooplankton. Late juvenile and adult bivalves can capture and ingest protozoans (Kemp et al. 1990, Kreeger \& Newell 1996), and can obtain some nutrition from particles of detritus (Crosby et al. 1990). Although early juvenile barnacles may not use bacteria, they may be able to feed on other types of particles and thus avoid starvation when phytoplankton is scarce.

Starvation might be expected to be a strong selective pressure among early juveniles that rely on food resources that vary considerably in availability over time, as is often the case for phytoplankton. The present results, however, indicate that early juveniles of some species are effective at using bacteria as an alternative source of food, and can use bacteria as a sole source of particulate matter to support survival and growth. This is significant because bacterial abundance tends to be relatively high throughout the year, remaining $\geq 1 \times 10^{6}$ cells $\mathrm{ml}^{-1}$ in Hong Kong (Gosselin \& Qian 1997b) and elsewhere (Rivkin et al. 1986, Lucas et al. 1987. Wikner \& Hagström 1991, Turley 1993), whereas phytoplankton abundance is generally much more variable over time and space (Pae \& Yoo 1991, Litaker et al. 1993, Roff et al. 1995), and remains low $\left(\leq 10^{3}\right.$ cells $\left.\mathrm{ml}^{-1}\right)$ in Hong Kong waters during much of the year (Chiu et al. 1994, Qiu \& Qian 1997 and references therein). Heterotrophic bacteria can indeed constitute a considerable pool of organic carbon in coastal waters. While protozoans are known to be important grazers of bacteria (Putt et al. 1991, Wikner \& Hag- ström 1991, Leakey et al. 1996), it is also becoming increasingly clear that a strong trophic link exists between marine bacteria and suspension feeding benthic invertebrates. Recent studies have demonstrated that bacteria may be used by several suspension feeders as a food source during their larval phase (Rivkin et al. 1986, Douillet 1993, Gosselin \& Qian 1997b), early juvenile phase (this study), or late juvenile/adult phase (Crosby et al. 1990, Langdon \& Newell 1990, Chalermwat et al. 1991, Kreeger \& Newell 1996).

In addition to the above implications for life history and energy flow, these results have interesting ramifications for the design of experiments examining the effects of food availability for suspension feeders. Since at least some larvae and early juveniles can use bacteria as a significant food source, studies requiring treatments that provide no food or very low food levels to suspension feeders should control or at least account for bacterial concentrations, unless there is evidence that the study organisms are not bacterivores, as for Balanus amphitrite in the present study.

Acknowledgements. We would like to thank S. Lau for providing original stocks of the 4 bacterial strains used in the present study. Also thanks to E. Boulding for conments on a previous version of the manuscript, and to $\mathrm{S}$. Chiu and L. Soo for technical support. This work was supported by $R G C$ grants HKUST 574/95M and ECWW95/96.SC02 to P.Y.Q., and a SAC grant from UCC to L.A.G. L.A.G. was also supported by a postdoctoral fellowship from the Department of Biology, HKUST, and DAG and ECF grants to P.Y.Q

\section{LITERATURE CITED}

Chalermwat K, Jacobsen TR, Lutz RA (1991) Assimilation of bacteria by the dwarf surf clam Mulinia lateralis (Bivalvia: Mactridae). Mar Ecol Prog Ser 71:27-35

Chiu HMC, Hodgkiss IJ, Chan BSS (1994) Ecological studies of phytoplankton in Tai Tam Bay, Hong Kong. Hydrobiologia 273:81-94

Cloern JE (1991) Tidal stirring and phytoplankton bloom dynamics in an estuary. J Mar Res 49:203-221

Cotner JB, Gardner WS, Johnson JR, Sada RH, Cavaletto JF, Heath RT (1995) Effects of zebra mussels (Dreissena polymorpha) on bacterioplankton: evidence for both sizeselective consumption and growth stimulation. J Great Lakes Res 21:517-528

Crosby MP, Newell RIE, Langdon CJ (1990) Bacterial mediation in the utilization of carbon and nitrogen from detrital complexes by Crassostrea virginica. Limnol Oceanogr 35: $625-639$

Douillet $P$ (1993) Carbon contribution through bacterivory in larvae of the Pacific oyster Crassostrea gigas. Mar Ecol Prog Ser 102:303-314

Gosselin LA (1997) An ecological transition during juvenile life in a marine snail. Mar Ecol Prog Ser 157:185-194

Gosselin LA, Qian PY (1997a) Juvenile mortality in benthic marine invertebrates. Mar Ecol Prog Ser 146:265-282

Gosselin LA, Qian PY (1997b) Can bacterivory alone sustain 
larval development in the polychaete Hydroides elegans and the barnacle Balanus amphitrite? Mar Ecol Prog Ser 161:93-101

Hentschel BT (1998) Spectrofluorometric quantification of neutral and polar lipids suggests a food-related recruitment bottleneck for juveniles of a deposit-teeding polychaete population. Limnol Oceanogr 43:543-549

Hurlbert SH (1984) Pseudoreplication and the design of ecological field experiments. Ecol Monogr 54:187-211

Jaeckle WB (1994) Rates of energy consumption and acquisition by lecithotrophic larvae of Bugula neritina (Bryozoa: Cheilostomata). Mar Biol 119:517-523

Kemp PF, Newell SY, Krambeck C (1990) Effects of filterfeeding by the ribbed mussel Geukensia demissa on the water-column microbiota of a Spartina alternifiora saltmarsh. Mar Ecol Prog Ser 59:119-131

Kreeger DA, Newell RIE (1996) Ingestion and assimilation of carbon from cellulolytic bacteria and heterotrophic flagellates by the mussels Geukensia demissa and Mytilus edulis (Bivalvia, Mollusca). Aquat Microb Ecol 11:205-214

Langdon CJ, Newell RIE (1990) Utilization of detritus and bacteria as food sources by two bivalve suspension-feeders, the oyster Crassostrea virginica and the mussel Geukensia demissa. Mar Ecol Prog Ser 58:299-310

Lau SCK, Qian PY (1997) Phlorotannins and related compounds as larval settlement inhibitors of the tube-building polychaete Hydroides elegans. Mar Ecol Prog Ser 159: 219-227

Leakey RJG. Archer SD, Grey J (1996) Microbial dynamics in coastal waters of East Antarctica: bacterial production and nanoflagellate bacterivory. Mar Ecol Prog Ser 142:3-17

Lee S, Fuhrman JA (1987) Relationships between biovolume and biomass of naturally derived marine bacterioplankton. Appl Environ Microbiol 53:1298-1303

Litaker W, Duke CS, Kenney BE, Ramus J (1993) Short-term. environmental variability and phytoplankton abundance in a shallow tidal estuary. II. Spring and fall. Mar Ecol Prog Ser 94.141-1.54

Lucas MI, Newell RC, Shumway SE, Seiderer LJ, Bally R (1987) Particle clearance and yield in relation to bacterioplankton and suspended particulate availability in estuarine and open coast populations of the mussel Mytilus edulis. Mar Ecol Prog Ser 36:215-224

Marsh AG, Tenore KR (1990) The role of nutrition in regulating the population dynamics of opportunistic, surface deposit feeders in a mesohalune community. Limnol Oceanogr 35:710-724

Morton B, Morton J (1983) The sea shore ecology of Hong Kong. Hong Kong University Press, Hong Kong

Okamura B (1990) Particle size, flow velocity; and suspensionfeeding by the erect bryozoans Buguld neritina and $B$. stolonifera. Mar Biol 105:33-38

Okamura B (1992) Microhabitat variation and patterns of colony growth and feeding in a marine bryozoan. Ecology $73: 1502-1513$

Pae SJ, Yoo SJ (1991) Short term variability of the phytoplankton populations in Masan Bay: 1. Dynamics J Oceanol Soc Korea 26:67-76

Editorial responsibility: Otto Kinne (Editor), Oldendorf/Luhe, Germany
Phillips NW (1984) Role of different microbes and substrates as potential suppliers of specific, essential nutrients to marine detritivores. Bull Mar Sci 35:283-298

Pile AJ, Patterson MR, Witman JD (1996) In situ grazing on plankton <10 $\mu \mathrm{m}$ by the boreal sponge Mycale lingua. Mar Ecol Prog Ser 141:95-102

Pitcher GC, Walker DR, Mitchell-Innes BA, Moloney CL (1991) Short-term variability during an anchor station study in the southern Benguela upwelling system: phytoplankton dynamics. Prog Oceanogr 28:39-64

Putt M, Stoecker D, Altstatt J (1991) Bacterivory in McMurdo Sound: 1 Grazing by heterotrophic nanoflagellates. Antarct J US 26:139-140

Qiu JW, Qian PY (1997) Combined effects of salinity, temperature and food on early development of the polychaete Hydroides elegans. Mar Ecol Prog Ser 152:79-88

Reiswig HM (1971) Particle feeding in natural populations of three marine demosponges. Biol Bull 141:568-591

Rivkin RB, Bosch I, Pearse JS, Lessard EJ (1986) Bacterivory a novel feeding mode for Asteroid larvae. Science 233 $1311-1314$

Roff JC, Turner JT, Webber MK, Hopcroft RR (1995) Bacterivory by tropical copepod nauplii: extent and possible signuficance. Aquat Microb Ecol 9:165-175

Schleyer MH (1981) Microorganisms and detritus in the water column of a subtidal reef of Natal. Mar Ecol Prog Ser 4: $307-320$

Shimeta J (1993) Diffusional encounter of submicrometer particles and small cells by suspension feeders. Limnol Oceanogr 38:456-465

Shimeta J, Jumars PA (1991) Physical mechanisms and rates of particle capture by suspension feeders. Oceanogr Mar Biol Annu Rev 29:191-257

Suzuki MT, Sherr EB, Sherr BF (1993) DAPI direct counting underestimates bacterial abundances and average cell size compared to AO direct counting. Limnol Oceanogr $38: 1566-1570$

Turley CM (1993) Direct estimates of bacterial numbers in seawater samples without incurring cell loss due to sample storage. In: Kemp PF, Sherr BF, Sherr EB, Cole JJ (eds) Handbook of methods in aquatic microbial ecology. Lewis Publishers, Boca Raton, p 143-147

Wikner J, Hagstrom $\AA$ (1991) Annual study of bacterioplankton community dynamics. Limnol Oceanogr 36:1313-1324

Woollacott RM, Pechenik JA, Imbalzano KM (1989) Effects of duration of larval swimming period on early colony development in Bugula stolonifera (Bryozoa: Cheilostomata). Mar Biol 102:57-63

Wright RT, Coffin RB, Ersing CP, Pearson D (1982) Field and laboratory measurements of bivalve filtration of natural marine bacterioplankton. Limnol Oceanogr 27:91-98

Zajac RN, Whitlatch RB, Osman RW (1989) Effects of interspecific density and food supply on survivorship and growth of newly settled benthos. Mar Ecol Prog Ser 56: $127-132$

Ziemann DA, Conquest LD, Olaizold M, Bienfang PK (1991) Interannual variability in the spring phytoplankton bloom in Auke Bay. Alaska. Mar Biol 109:321-334 